\title{
Gametogenesis and gonad mass cycles in the common circumpolar Antarctic echinoid Sterechinus neumayeri
}

\author{
S. Brockington ${ }^{1}$, L. S. Peck ${ }^{1, *}$, P. A. Tyler ${ }^{2}$ \\ ${ }^{1}$ British Antarctic Survey, Natural Environment Research Council, High Cross, Madingley Road, Cambridge CB3 0ET, UK \\ ${ }^{2}$ Southampton Oceanography Centre, Natural Environment Research Council, European Way, Southampton, \\ Hants SO14 3ZH, UK
}

\begin{abstract}
Polar conditions (low and stable seawater temperature coupled with highly seasonal primary productivity) constrain reproduction in benthic invertebrates. The reproductive cycle of the common Antarctic sea urchin Sterechinus neumayeri was investigated at monthly intervals over a $2 \mathrm{yr}$ period in relation to seasonality of chlorophyll standing stock and ability to feed. Competence to spawn increased gradually throughout the austral winter to peaks in September to November. Gonad mass varied strongly, both seasonally and among 3 geographically close sites. Spawning occurred between October and January at each site, and was strongest in November of both years. Spawning was not always accompanied by a reduction in gonad mass because of simultaneous feeding and deposition of nutritive tissue for the forthcoming winter. Spawning was annual but there was also strong evidence for longer, multi-year periodicity in reproductive output. Histological analysis indicated an 18 to 24 mo vitellogenic cycle, with oocytes developing from 20 to $50 \mu \mathrm{m}$ in the first winter, and from 50 to $120 \mu \mathrm{m}$ in the second winter. Of total oocyte volume increase (vitellogenesis), 93\% occurred within the last $12 \mathrm{mo}$. Spermatogenesis took $12 \mathrm{mo}$. S. neumayeri does not feed during the austral winter, and vitellogenesis is therefore predominantly decoupled from energy intake. Much of the cost of reproductive synthesis is met at a time of severe energy limitation.
\end{abstract}

KEY WORDS: Gonad mass $\cdot$ Seasonality $\cdot$ Reproductive cycle $\cdot$ Vitellogenesis $\cdot$ Urchin

\section{INTRODUCTION}

Gametogenesis within the Echinoidea has been well studied, and all species display an ordered sequence of events from initial gonial proliferation through spermatogenesis or vitellogenesis to final maturation of gametes (Pearse \& Cameron 1991). Different species show a broad range of reproductive periodicities, many of which are influenced by environmental factors, in particular nutrition and temperature (Lawrence \& Lane 1982, Minor \& Scheibling 1997). Gonad size and gamete output is strongly related to food availability, but there are few data to demonstrate that nutrition plays a role in regulating the initiation of gametogene- sis (Pearse \& Cameron 1991). Temperature has often been viewed as a gametogenic regulator, but evidence is generally correlational except for species inhabiting areas with marked natural annual temperature regimes.

Polar latitudes provide a unique environment with extremely low and constant temperatures contrasting with highly seasonal food limitation (Clarke 1988, Peck et al. 2006). Under these conditions the polar benthos have evolved to be generally stenothermal with low metabolic rates, slow annual growth and extended longevity (Arntz et al. 1994, Peck 2005, Peck et al. 2006). Whilst low temperatures have facilitated the overall reduction in metabolic rates, the highly sea- 
sonal cycle of autotrophic production has led to strongly restricted feeding opportunities for many species during the polar winter (Barnes \& Clarke 1995, Brockington et al. 2001). Metabolically active processes such as somatic growth are therefore often confined to summer periods of autotrophic production. As a consequence, somatic growth is slow or absent during winter for many Antarctic species, resulting in extended longevity (Dayton et al. 1974, Clarke 1988). However, a few Antarctic species such as the infaunal bivalve mollusk Yoldia eightsi (Peck et al. 2000) and the brachiopod Liothyrella uva (Peck et al. 1997) have been shown to have a growth period not correlated with periods of food supply.

Because vitellogenesis is extended at low temperature locations, food conditions may strongly affect reproductive periodicities (Pearse \& Cameron 1991). Therefore, at higher latitudes, the metabolic cost of gametogenesis may have to be met during the polar winter when both metabolic rate and feeding are reduced (Brockington et al. 2001, Fraser et al. 2002a,b). Furthermore, it has been suggested that the effects of seasonal energy limitation combined with extended longevity may balance a reduction in annual reproductive output (i.e. mass of gametes released), so that lifetime reproductive effort is similar to that of a comparable non-polar species (Clarke 1987, Brey et al. 1995). Although somatic growth has been moderately well studied for benthic polar echinoids, both by direct observation and via indirect methods (e.g. growth band counts) (e.g. Brey et al. 1995, Brockington 2001), reproductive growth has been less well evaluated, mainly owing to sampling difficulties.

Sterechinus neumayeri (Meissner, 1909) is a regular echinoid endemic to the Antarctic, has a circumpolar distribution and is locally very abundant at Rothera Point on the Antarctic Peninsula (Brockington 2001). The present study recorded gonad mass at monthly intervals for 3 populations of $S$. neumayeri over a 25 mo period. Data presented here, combined with assessments of seasonality of both energy intake (Brockington et al. 2001) and metabolism (Brockington \& Peck 2001), facilitate evaluations of life history constraints under polar conditions.

\section{MATERIALS AND METHODS}

Pelagic primary production has important implications for feeding in benthic detritivores and herbivores via downward flux and advection of phytoplankton. Seawater chlorophyll standing stock was measured weekly as described by Brockington et al. (2001). Sterechinus neumayeri feeding activity, measured as rate of faecal egestion, was simultaneously recorded at the same locations and reported by Brockington et al. (2001).

Sterechinus neumayeri were collected by SCUBA divers at monthly intervals from 3 locations near the British Antarctic Survey Research Station at Rothera Point, Adelaide Island (Fig. 1). The North Cove site was adjacent to the northern extremity of the station
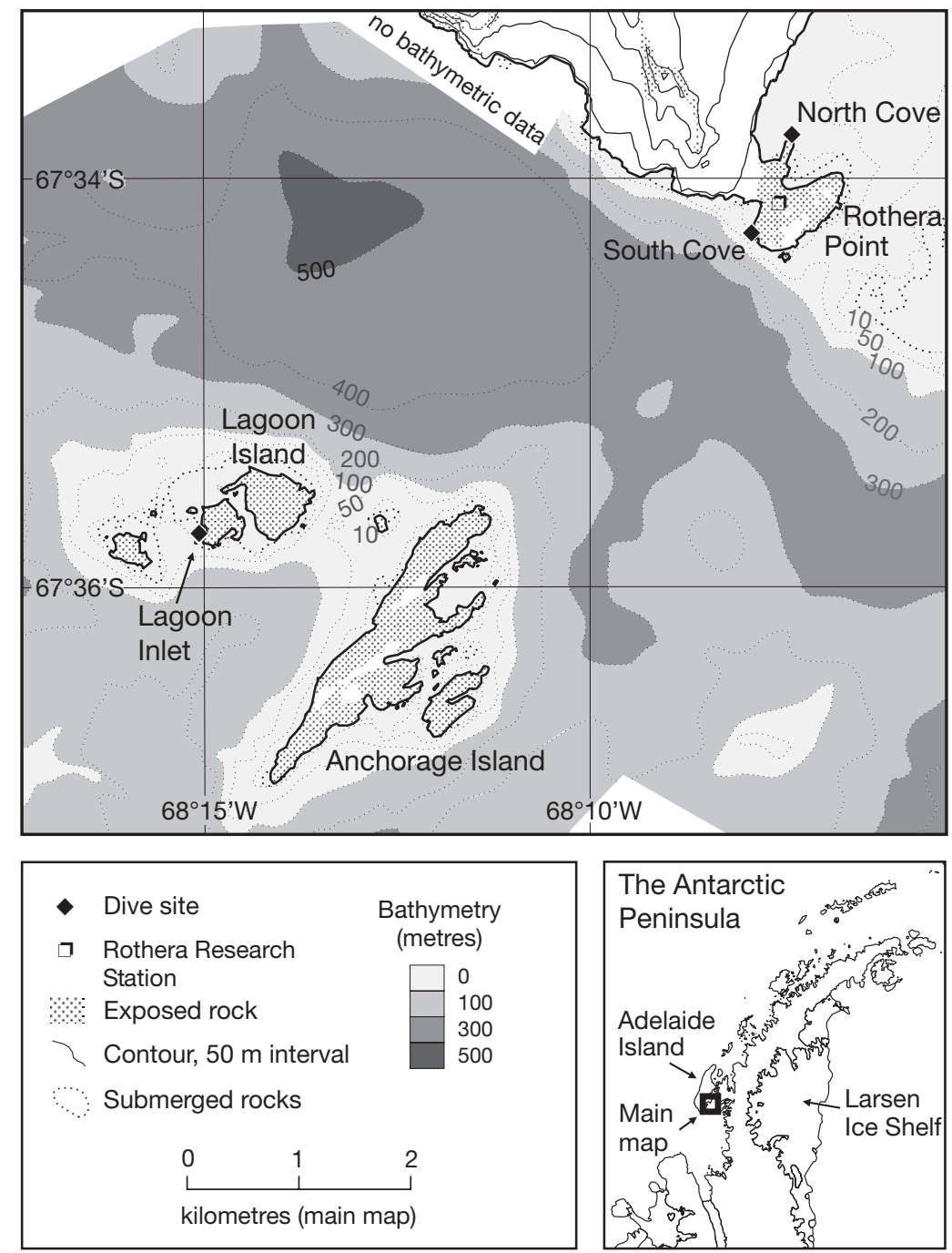

Fig. 1. Rothera Point, Adelaide Island, showing location of sampling locations; the site of the Rothera Time Series oceanographic monitoring programme (RaTS) was $500 \mathrm{~m}$ to the west of this map 
runway, where urchins were collected from a sediment substratum at $29 \mathrm{~m}$ depth. At South Cove, urchins were collected from a hard rock substratum between 6 and $10 \mathrm{~m}$ depth. At the third site (Lagoon Island) urchins were collected at 4 to $6 \mathrm{~m}$ depth from a cobble/boulder beach. At each site, samples were repeatedly collected from areas less than $20 \mathrm{~m}$ apart; transit lines were used to accurately identify sample sites. The cobble/boulder beach at Lagoon Island was a consistent substratum over an area of several hundred square metres, and so was homogenous in terms of sampling regime. All sites were within $6 \mathrm{~km}$ of each other. Gonad mass and competence to spawn was assessed at all 3 sites, and histological investigation of reproductive periodicity was also performed on specimens from North Cove.

Sea urchins were returned to the laboratory after collection and sorted to remove adherent debris. Test diameter was measured in 3 horizontal directions using knife-edged calipers, and a mean value calculated. Dry gonad mass was obtained by placing eviscerated tissue into pre-weighed crucibles and drying to constant mass at $60^{\circ} \mathrm{C}$. Gonad mass was regressed against test diameter after logarithmic transformation of both variables from a large sample:

$$
\begin{gathered}
\ln \text { gonad }=2.76 \times \ln \text { test diameter }-9.98 \\
\left(\mathrm{r}^{2}=0.823 ; F=186.08 ; \mathrm{n}=40\right)
\end{gathered}
$$

where gonad mass is measured in grams and test diameter in $\mathrm{mm}$.

Subsequently, dry gonad mass was determined from 10 sea urchins on each sampling occasion, using sea urchins with test diameters that were as close to $30 \mathrm{~mm}$ as possible. Specimens ranged from 27.8 to $32.6 \mathrm{~mm}$ diameter, so the necessary corrections to standard animal values were very small. Gonad index was not calculated because the index may be altered through the year by simultaneous changes in the mass of other tissues (e.g. gut mass; Lawrence et al. 1965). Instead, the scaling exponent from Eq. (1) was used to arithmetically correct for small differences in test size by adjusting gonad mass to that of a standard $30 \mathrm{~mm}$ test diameter urchin.

Competence to spawn was assessed at each site on each sampling occasion by the injection of 0.5 to $1.0 \mathrm{ml}$ of $0.5 \mathrm{M} \mathrm{KCl}$ in seawater into the coelom of 10 urchins (Bosch et al. 1987). After injection, urchins were held individually in clean seawater in $500 \mathrm{ml}$ beakers and maintained at environmental seawater temperature. Any gamete discharge was recorded after $12 \mathrm{~h}$. Spawning events were also observed both directly by SCUBA divers and from the time-course of vitellogenesis as determined from histological investigation. Spawning observations were made during the monthly sampling, and any spawning that occurred following disturbance by divers or for other reasons was noted.
At roughly monthly intervals, reproductive condition was assessed histologically for 5 male and 5 female sea urchins collected from North Cove only. Specimens were collected simultaneously with urchins intended for the gonad mass study, and fixed by injection and immersion into $4 \%$ formal saline. Samples were stored at $+5^{\circ} \mathrm{C}$, and when necessary the preservative changed after 12 mo. Specimens were returned to the UK, dissected, and gonad samples dehydrated in an alcohol series followed by immersion in histoclear before being embedded in wax. Sections were cut at $7 \mu \mathrm{m}$ on a hand microtome and stained using Haematoxylin 'Z' and Putts Eosin (Cellpath).

Reproductive condition was assessed for female urchins as oocyte feret (i.e. mean) diameter. Sections were examined at $\times 100$, and feret diameters of 100 oocytes per individual were calculated using Sigmascan image analysis software (Jandel Scientific). Thus, 500 oocyte diameters were recorded each month over a 21 mo period. For male urchins, testis development was classified into 5 maturity stages modified from the methods of Byrne (1990) and Fuji (1960).

Stage 1. Spent: Lumen empty or resorption of relict gametes in progress. Nutritive phagocytic tissue highly eosinophilic and of variable thickness. No evidence of new spermatogenesis.

Stage 2. Initial development: Nutritive tissue clearly eosinophilic and of medium thickness. Blue primary spermatocytes visible on germinal epithelium. First traces of spermatozoa in lumen.

Stage 3. Developing: Nutritive tissue stains more readily with haematoxylin (i.e. more blue). Blue primary spermatocytes visible on germinal epithelium and forming spermatid towers into lumen. Moderate density of spermatozoa in lumen.

Stage 4. Mature: Lumen full of densely packed mature spermatozoa in swirls. Lumen intense blue. Spermatid production may still be evident. Nutritive tissue generally highly reduced.

Stage 5. Spawning: Reduced density of mature spermatozoa. No spermatid production evident. Thickness of nutritive tissue highly variable, and becoming eosinophilic.

\section{RESULTS}

$\mathrm{KCl}$ injection showed that urchins from all sites had synchronised reproductive cycles: all sites exhibited high spawning competences in late winter, mainly in October and November of both years (Fig. 2). This coincided with SCUBA divers' observations of spawning in the field. At both North Cove and Lagoon Island, spawning competence increased gradually in the austral winter, even though males predominantly 


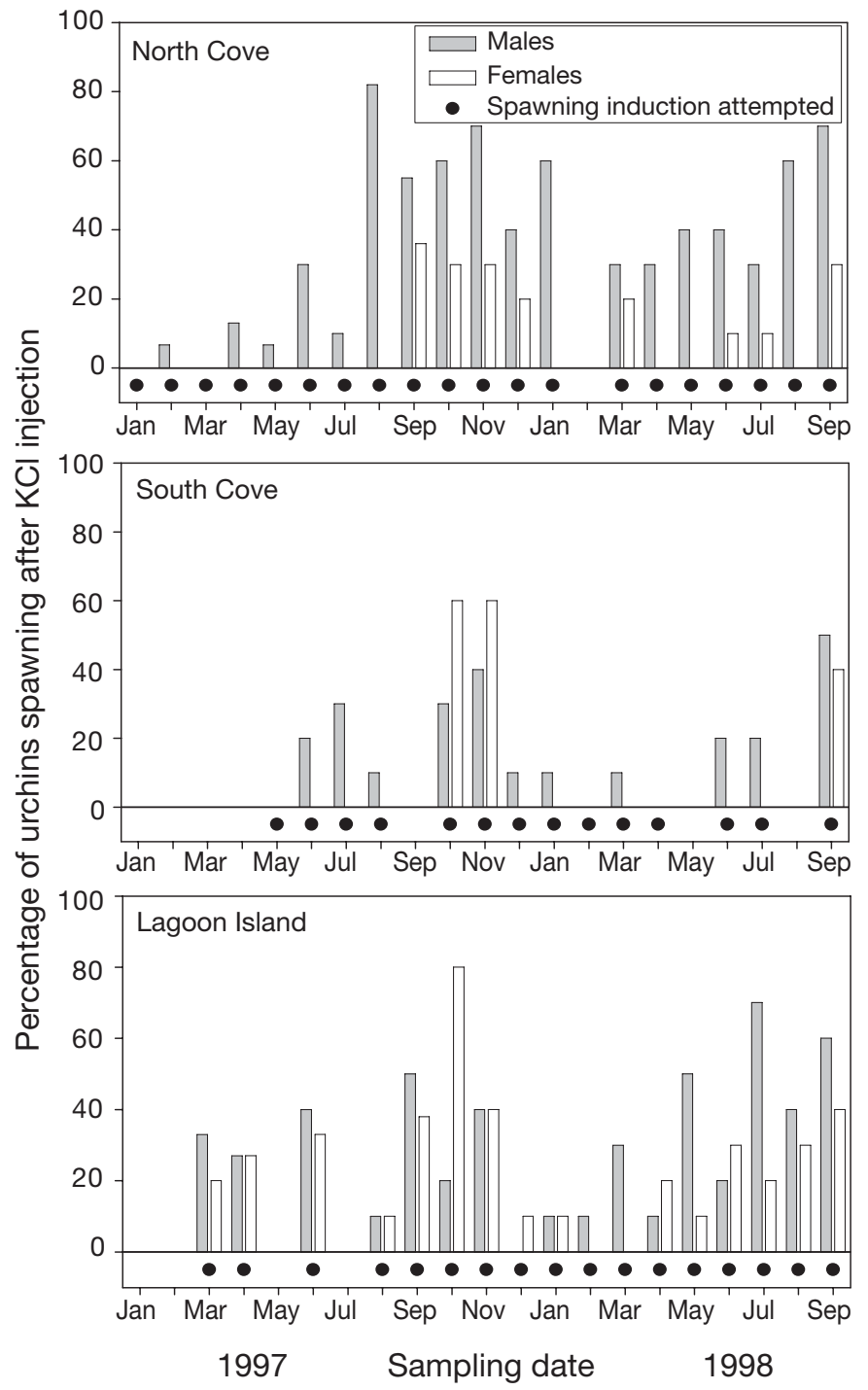

Fig. 2. Sterechinus neumayeri. Seasonal cycle in competence to spawn at 3 sites around Rothera Point; $\bullet$ : dates when 10 individuals were injected with $0.5 \mathrm{ml} \mathrm{KCl}$; bars represent proportion of individuals spawning

spawned more readily than females. Spawning competence was usually lower at South Cove than at the other 2 sites.

Gonad mass differed greatly both among sites and between years (Fig. 3). Paradoxically, gonad mass increased at the start of the 1998 austral summer but not in 1997, despite spawning being observed by divers at all sites between November and January in both years. Sea urchins from South Cove had the lowest gonad mass in the study (0.05 to $0.32 \mathrm{~g}$ dry mass per standard individual), and no change in mass occurred either at spawning or between years, with the exception of a rise at the start of the 1998/99 austral summer. Gonad mass of North Cove urchins increased during the 1997/98 austral summer, and remained higher throughout the 1998 winter compared with 1997. The coeloms of urchins from Lagoon Island during the 1997 winter were completely filled with reproductive tissue, and gonad masses at this time from this site were the highest recorded ( 0.62 to $0.75 \mathrm{~g}$ dry mass per standard individual). Mass reduced to much lower values during a major spawning event in the 1997/98 austral summer, remained at intermediate levels throughout the 1998 winter, and rose again at the onset of the following austral summer.

A gametogenic cycle lasting 18 to $24 \mathrm{mo}$, characterised by spawning events in the late winter/early summer of 1997 and 1998, was clearly present in oocyte size frequency distributions measured from histological sections (Fig. 4). In August of both years there were only 2 cohorts of oocytes, one nearly full grown at roughly $120 \mu \mathrm{m}$ diameter, and a second of 40 to $60 \mu \mathrm{m}$ diameter. By September of both years the full grown cohort was unchanged in diameter, but secondary oocytes had begun to mature to form ova prior to spawning in November. Mean size of the smaller cohort decreased in September 1997, and this cohort then divided into 2 in September 1998 as the new population of pre-vitellogenic oocytes proliferated in the ovaries. The 2 smaller cohorts of oocytes were then observed over the course of the experimental period, with the middle cohort (40 to $60 \mu \mathrm{m}$ in September and October 1997) maturing to spawn in late 1998, and the smallest cohort (20 $\mathrm{mm}$ in September 1997) maturing to spawn in late 1999. Despite the overall prolonged developmental period, $93 \%$ of volume increase of developing oocytes (equivalent to an increase in diameter from 50 to $120 \mu \mathrm{m}$ ) occurred during the last 12 mo of the cycle (November to November), with the initial increase over 6 to 12 mo from 20 to $50 \mu \mathrm{m}$ accounting for only $7 \%$ of final volume.

The final major vitellogenic phase began in January. This phase of volume increase proceeded at a steady rate throughout the austral winter until August-September, when maximum oocyte diameter $(120 \mu \mathrm{m})$ was attained. From September onwards, post-vitellogenic secondary oocytes matured to become ova without further increase in size. Mature ova were released as part of a synchronous spawning event over a 2 mo period from November onwards.

Spermatogenesis exhibited a 12 mo cycle (Fig. 5). Fully spent testes were observed mainly between November and February following the annual spawning event; however, spent urchins were also encountered sporadically at other times. In late summer (March and April), the thickness of eosinophilic nutritive phagocytic tissue increased to fill the testicular lumen (Brockington 2001). Primary spermatocytes became visible on the germinal epithelium in April and May, and these started to form towers of spermatids by 


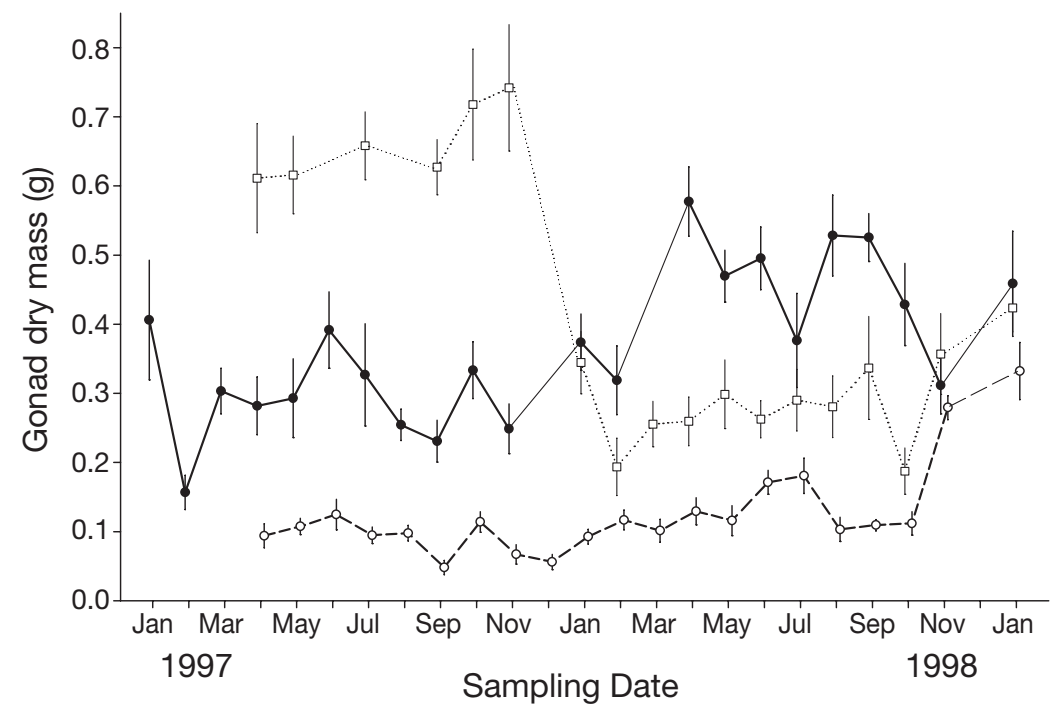

Fig. 3. Sterechinus neumayeri. Seasonal variation in gonad dry mass at

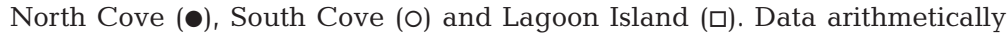
standardised to an urchin of $30 \mathrm{~mm}$ test diameter and presented as mean $\pm \mathrm{SE}(\mathrm{n}=10)$ mid-winter. Spermatid development and reduction in thickness of nutritive phagocytic tissue progressed steadily throughout the austral winter. Mature sperm were observed in dense concentrations in the testis lumen by October, and spawning took place from November onwards.

\section{DISCUSSION}

Low winter chlorophyll concentrations (in the range of 0.05 to $0.2 \mathrm{mg} \mathrm{m}^{-3}$ ) persisted for 142 d in 1997 and 159 d in 1998, and resulted in a complete cessation of sea urchin feeding activity for around 7 mo in the first year of this study and $4 \mathrm{mo}$ in the second year (Brockington et al. 2001). A single intense bloom occurred early in the 1997/98 austral summer and coincided with the breakout time of the winter fast ice. At

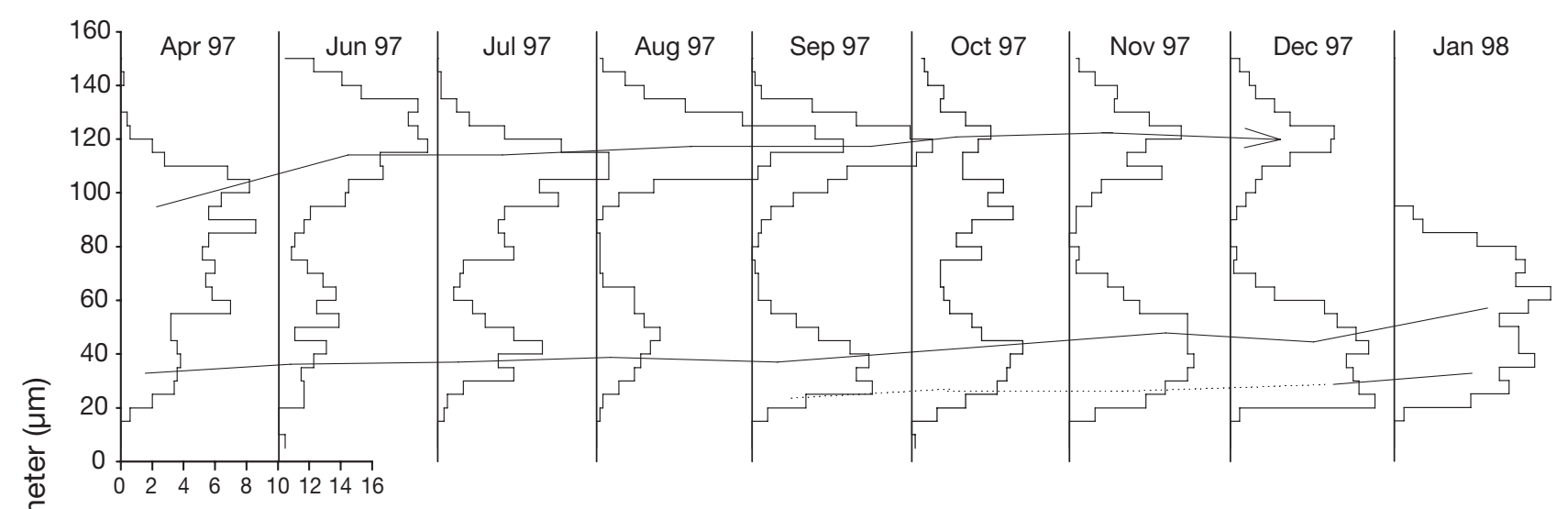

중

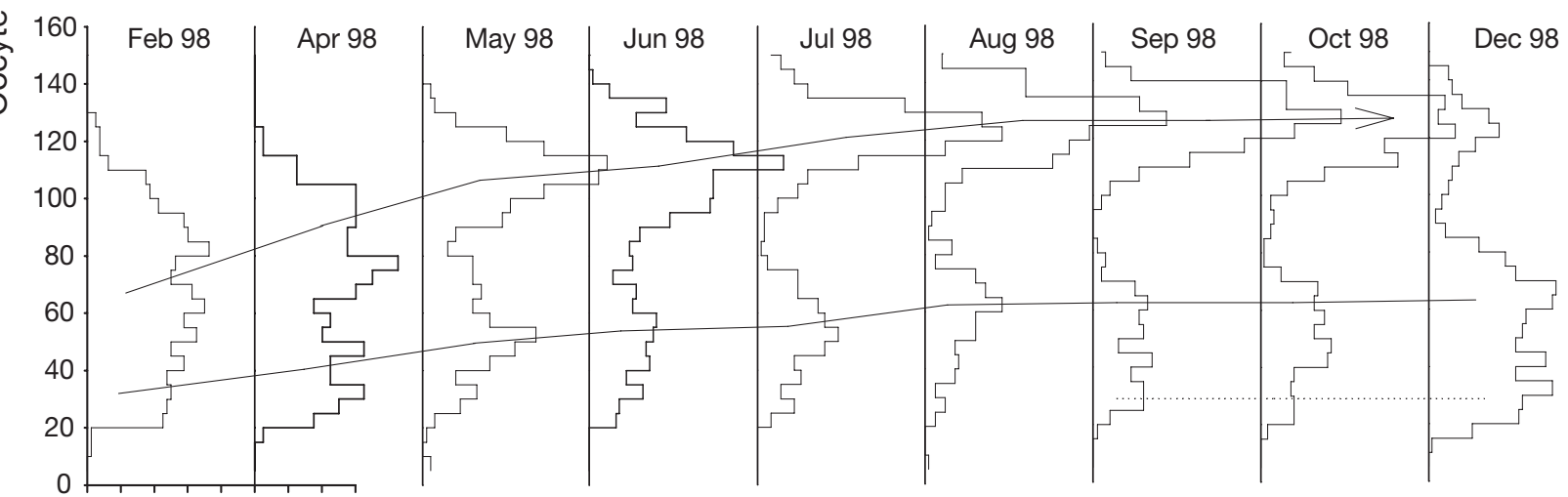

$\begin{array}{lllllllll}0 & 2 & 4 & 6 & 8 & 10 & 1214 & 16\end{array}$

Percentage frequency

Fig. 4. Sterechinus neumayeri. Oocyte feret diameter frequency at North Cove in $5 \mu \mathrm{m}$ size classes; $\mathrm{n}=500$ ind. $\mathrm{mo}^{-1}(5 \mathrm{females}$, 100 oocytes each) except in February $1998(n=400)$, April $1998(n=200)$ and September $1998(n=400):$ total $n=8500$ 


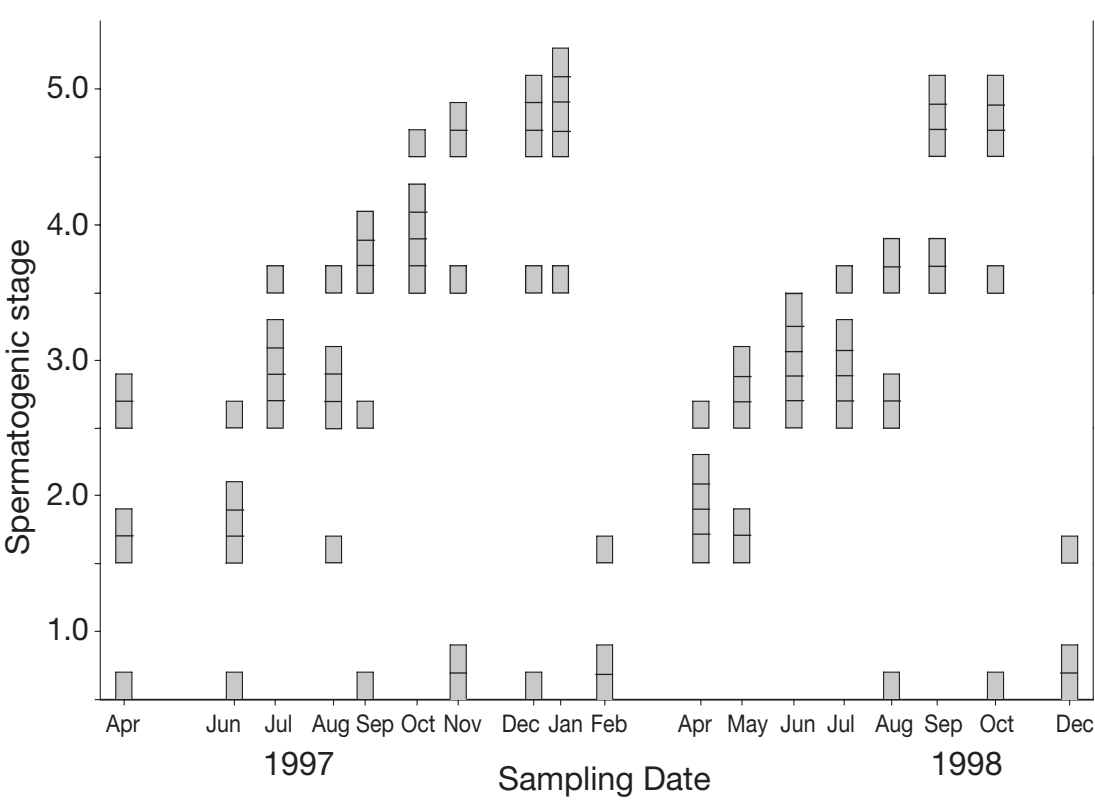

Fig. 5. Sterechinus neumayeri. Maturation stage of testis $\left(\mathrm{n}=5 \mathrm{ind} . \mathrm{mo}^{-1}\right)$ at North Cove. Each box represents the maturation stage of an individual. When more than 1 urchin had the same maturity stage at any date, boxes for individuals are stacked to form bars; 1 yr spermatogenic cycles are exhibited in both 1997 and 1998, as mean maturation stage progresses from < 2 in April to $>4$ in September

its peak this bloom reached a chlorophyll concentration of over $24 \mathrm{mg} \mathrm{m}^{-3}$, which contrasted with the less intense early and late summer blooms (15 to $20 \mathrm{mg} \mathrm{m}^{-3}$ ) in 1998/99. The development of fast ice during the 1998 winter was on a considerably smaller scale than that in 1997, and the extra light penetrating the water column in 1998 probably allowed for the earlier development of the phytoplankton bloom in November.

The fact that echinoids can survive over a wide range of habitat types has been related to their ability to display varying degrees of morphological plasticity under differing environmental regimes (Marcus 1983). In Strongylocentrotus purpuratus, reduced food availability causes a relative increase in mass of Aristotle's lantern and decrease in mass of gut under laboratory conditions (Ebert 1996). In the field, sea urchin populations from nutritionally poor areas with such adaptations have survival rates comparable to those from other regions, indicating that these phenotypic responses enhance survival (Ebert 1996). Notwithstanding, one of the most pronounced morphological responses to reduction in food availability is reduction in gonad size (Lawrence \& Lane 1982, Nichols et al. 1985, Minor \& Scheibling 1997). For populations from areas of reduced food, this inevitably leads to reduced reproductive output; however, Thompson (1984) demonstrated that Strongylocentrotus droebachiensis allocates more energy to reproduction under poor food conditions, thereby increasing reproductive effort, even though reproductive output is ultimately lower.

The variation in gonad mass recorded for the 3 Sterechinus neumayeri populations around Rothera Point cannot easily be explained in terms of food availability. Macroalgal biomass at Rothera Point is very low, and urchins from the soft bottom population at North Cove ingested only sediment. $S$. neumayeri at both South Cove and Lagoon Island (with the lowest and highest gonad masses, respectively) consumed a similar diet, comprising a large proportion of sediment but also crustaceans, macroalgae fragments, polychaetes, bryozoans and occasional seal faeces (Brockington et al. 2001). Therefore, food quality is unlikely to account for among-site differences in gonad mass. Rates of feeding (estimated as rate of faecal egestion on a dry mass or ash-free dry mass basis) were highest at North Cove and very similar at South Cove (Brockington et al. 2001), suggesting that food quantity was also not responsible. Very large interannual differences in gonad mass patterns among sites further suggest that gonad mass is not primarily controlled by food availability at Rothera Point. Throughout 1997, the gonad mass of the Lagoon Island population was the highest of the 3 sites measured; however, this declined sharply to a lower and more stable level in 1998 without any apparent change in site characteristics, food availability or population density. Furthermore, in early 1999, gonad mass of the South Cove population increased sharply to intermediate values, comparable with those of both the North Cove and Lagoon Island populations. One of the main food sources for these populations is sedimented and advected material derived from the phytoplankton bloom. Blooms in both 1997/98 and 1998/99 were intense, reaching chlorophyll standing stock values well in excess of $15 \mathrm{mg} \mathrm{m}^{-3}$ (Brockington et al. 2001). It is, therefore, unlikely that food supply was more restricting in the latter half of the study than the first half at any site.

Differences in sea urchin size are also unable to account for these differences: similar sized urchins were used throughout, and small differences in mass were corrected arithmetically using a scaling coefficient. Population density was similar at all 3 sites (Brockington 2001). The remaining most likely explanation is that reproduction of Sterechinus neumayeri varies over several cycles of differing length. There is a seasonal build-up of gonad mass with an annual spawning 
event, but this is overlaid on a much longer cycle of gonad mass over a period of several years, culminating in a substantial spawning event such as that observed in the Lagoon Island population in the 1997/98 austral summer. The Antarctic brittle star Ophionotus victoriae, also sampled from South Cove, exhibited extreme interannual variations in reproductive output over a 3.4 yr period (between September 1997 and December 2000; Grange et al. 2004), suggesting the possibility of a long-term reproductive cycle. A circaseptennial rhythm ( 7 yr cycle) was tentatively proposed for Strongylocentrotus purpuratus based on 114 monthly collections of data over a $10 \mathrm{yr}$ period (Halberg et al. 1987). Our data do not rule out a cycle of this duration.

From gametogenic stage, spermatogenic stage and spawning induction data, spawning was observed each year at each site. However, this was not generally associated with a reduction in gonad mass. The annual feeding period of Sterechinus neumayeri at Rothera Point is restricted to the summer months (Brockington et al. 2001), and we postulate that a reduction in mass on spawning was not observed because of rapid feeding activity and the deposition of nutritional reserves in the gonad.

Annual reproductive output as number or mass of gametes spawned varies markedly with a range of environmental factors, notably food supply and animal density (Lawrence \& Lane 1982). It is difficult to assess reproductive effort across latitudes, because it should be evaluated either on a basis of effort over the complete adult lifetime or in relation to the overall animal energy budget (Clarke 1987, 1992). Egg sizes also increase with decreasing seawater temperatures (Clarke 1992). This will affect the calculation of reproductive effort depending on whether gamete number or mass is used. Long-term studies of reproduction in Antarctic brachiopods (Meidlinger et al. 1998) and brittle stars (Grange et al. 2004) also revealed dramatic interannual variation in reproductive output. However, the only 2 studies of reproductive output in Antarctic echinoderms (McClintock 1989, Brockington 2001) both produced values that are comparable with the highest figures for temperate species (Brockington 2001). This suggests that reproductive effort may not be constrained by temperature in the way that it is by food supply.

Gametogenesis in Sterechinus neumayeri at McMurdo Sound was reported to be 18 to 24 mo by Pearse \& Giese (1966) and Pearse \& Cameron (1991), but only 12 mo at Hasswell Island (Davis Sea) by Yakovlev (1983). However, the latter study did not include a quantitative examination of seasonal oocyte size frequencies, and may have failed to record the presence of smaller pre-vitellogenic oocytes amongst the larger maturing ova.
The time-course of vitellogenesis varies considerably among different echinoid species. Strongylocentrotus purpuratus has an oogenic cycle of 6 to 9 mo in California. Oocyte proliferation occurs in summer (May to August), ova accumulate in winter (December to March), and are spawned in late winter or early spring (Bayschmith \& Pearse 1987). This timing is very similar to that of Echinometra mathaei in the Gulf of Suez, and is about half the time required by Sterechinus neumayeri. Holland (1967) reported a 9 to 12 mo cycle for Stylocidaris affinis from Naples, and in southern California Centrostephanus coronatus has a 1 mo lunar cycle similar to that of Diadema spp. in the tropics (Pearse 1970). Although these results suggest that low water temperature does slow gametogenesis, other environmental factors (photoperiod, food availability) affect both timing of the initiation of gametogenesis and subsequent tempo. Environmental predictability was recently demonstrated to have a marked effect on the timing of biological events and the tempo of life histories in Antarctic environments (Peck et al. 2006), and many studies have shown that markedly extended periods are required for gametogenesis in other taxa from high latitudes including the starfish Odontaster validus (Pearse 1965), the brachiopod Liothyrella uva (Meidlinger et al. 1998), the amphipod Bovallia gigantean (Clarke 1988) and the brittle star Ophionotus victoriae (Grange et al. 2004). To date, the only species to show annual gametogenesis is the scallop Adamussium colbecki (Tyler et al. 2003). The patterns shown here for $S$. neumayeri therefore match those seen in other species at high latitude sites.

Sterechinus neumayeri displays a highly seasonal metabolic rate (Brockington \& Peck 2001). Long periods of low metabolic activity during the austral winter correspond to restricted feeding opportunities at that time (Brockington 2001). Over-wintering survival during this period of severe nutritional limitation has been attributed to the very low metabolic rates displayed by polar marine ectotherms, which allow highly efficient usage of stored reserves (Clarke 1988, Clarke \& Peck 1991). Low overall winter metabolic rates have been associated with suspension of metabolically expensive processes such as growth, coupled with a reduced basal metabolic requirement through reduced protein turnover (Clarke 1988). However, our study indicates that a significant portion of vitellogenesis occurs in winter (April to September, Fig. 4), when feeding is suspended. Although nutritive tissue to fuel gametogenesis is deposited during summer, thermodynamic costs of vitellogenesis must be met by stored reserves. The continuance of metabolically active processes such as gametogenesis during the energy-limited polar winter reinforces the hypothesis that survival is not a major physiological difficulty. 
Acknowledgements. This project would not have been possible without the help of many members of Rothera Research Station between 1997 and 1999, especially the dive team: Rob Wood, Steve Dunkerly, Stuart Wallace, Martin Warnock and Alice Chapman. Dawn Powell provided extensive training and help with histology, and Andrew Clarke and John Pearse provided comments which improved this manuscript. The manuscript was further improved by the comments of Prof. J. McClintock and 2 anonymous referees.

\section{LITERATURE CITED}

Arntz WE, Brey T, Gallardo VA (1994) Antarctic zoobenthos. Oceanogr Mar Biol Annu Rev 32:241-304

Barnes DKA, Clarke A (1995) Seasonality of feeding activity in Antarctic suspension feeders. Polar Biol 15:335-340

Bayschmith E, Pearse JS (1987) Effect of fixed daylengths on the photoperiodic regulation of gametogenesis in the seaurchin Strongylocentrotus purpuratus. Int J Invertebr Reprod Dev 11:287-294

Bosch I, Beauchamp K, Steele ME, Pearse J (1987) Development, metamorphosis and seasonal abundance of embryos and larvae of the Antarctic sea-urchin Sterechinus neumayeri. Biol Bull (Woods Hole) 173:126-135

Brey T, Pearse J, Basch L, McClintock J, Slattery M (1995) Growth and production of Sterechinus neumayeri (Echinoidea: Echinodermata) in McMurdo Sound, Antarctica. Mar Biol 124:279-292

Brockington S (2001) The seasonal ecology and physiology of Sterechinus neumayeri (Echinodermata: Echinoidea) at Adelaide Island, Antarctica. PhD thesis, British Antarctic Survey, Cambridge

Brockington S, Peck LS (2001) Seasonality of respiration and ammonia excretion in the Antarctic echinoid Sterechinus neumayeri. Mar Ecol Prog Ser 219:159-168

Brockington S, Clarke A, Chapman ALG (2001) Seasonality of feeding and nutritional status during the austral winter for the common Antarctic sea urchin Sterechinus neumayeri. Mar Biol 139:127-138

Byrne M (1990) Annual reproductive cycles of the commercial sea urchin Paracentrotus lividus from an exposed intertidal and a sheltered subtidal habitat on the west coast of Ireland. Mar Biol 104(2):275-289

Clarke A (1987) Temperature, latitude and reproductive effort. Mar Ecol Prog Ser 38:89-99

Clarke A (1988) Seasonality in the Antarctic marine environment. Comp Biochem Physiol 90B:461-473

Clarke A (1992) Reproduction in the cold: Thorson revisited. Invertebr Reprod Dev 22:175-184

Clarke A, Peck LS (1991) The physiology of polar marine zooplankton. Polar Res 10:355-369

Dayton PK, Robilliard GA, Paine RT, Dayton LB (1974) Biological accommodation in the benthic community at McMurdo Sound, Antarctica. Ecol Monogr 44:105-128

Ebert TA (1996) Adaptive aspects of phenotypic plasticity in Echinoderms. Oceanol Acta 19:347-355

Fraser KPP, Clarke A, Peck LS (2002a) Feast and famine in Antarctica: seasonal physiology in the limpet, Nacella concinna (Strebel, 1908). Mar Ecol Prog Ser 242:169-177

Fraser KP, Clarke A, Peck LS (2002b) Low temperature protein metabolism: seasonal changes in protein synthesis and RNA dynamics of the Antarctic limpet, Nacella concinna (Strebel, 1908). J Exp Biol 205:3077-3086

Fuji A (1960) Studies on the biology of the sea urchin. 1. Superficial and histological gonadal changes in gametogenic process of two sea urchins, Strongylocentrotus nudus and $S$. intermedius. Bull Fac Fish Hokkaido Univ 11:1-14

Grange LJ, Tyler PA, Peck LS, Cornelius N (2004) Long-term interannual cycles of the gametogenic ecology of the Antarctic brittle star Ophionotus victoriae. Mar Ecol Prog Ser 278:141-155

Halberg F, Shankaraiah K, Giese AC (1987) The chronobiology of marine invertebrates: methods of analysis. In: Giese AC, Pearse JS, Pearse VB (eds) Reproduction of marine invertebrates, Vol IX. General aspects: seeking unity in diversity. The Boxwood Press, Pacific Grove, CA, p 331-384

Holland N (1967) Gametogenesis during the annual reproductive cycle in a cidaroid sea urchin (Stylocidaris affinis). Biol Bull (Woods Hole) 128:241-258

Lawrence JM, Lane JM (1982) The utilization of nutrients by post metamorphic echinoderms. In: Jangoux M, Lawrence JM (eds) Echinoderm nutrition. AA Balkema, Rotterdam, p 331-372

Lawrence JM, Lawrence AL, Holland ND (1965) Annual cycle in the size of the gut of the purple sea urchin Stronglocentrotus purpuratus (Stimpson). Nature 205:1238-1239

Marcus NH (1983) Phenotypic variability in echinoderms. In: Jangoux M, Lawrence JM (eds), Echinoderm Studies, Vol 1. AA Balkema, Rotterdam, p 19-38

McClintock JB (1989) Energetic composition, reproductive output and resource allocation of Antarctic asteroids. Polar Biol 9:147-153

Meidlinger K, Tyler PA, Peck LS (1998) Reproductive patterns in the Antarctic brachiopod Liothyrella uva. Mar Biol 132: 153-162

Minor MA, Scheibling RE (1997) Effects of food ration and feeding regime on growth and reproduction of the sea urchin Stronglyocentrotus droebachiensis. Mar Biol 129: 159-167

Nichols D, Bishop GM, Sime AAT (1985) Reproductive and nutritional periodicities in populations of the European sea-urchin, Echinus esculentus (Echinodermata: Echinoidea) from the English Channel. J Mar Biol Assoc UK 65:203-220

Pearse JS (1965) Reproductive periodicities in several contrasting populations of Odontaster validus, Koehler, a common Antarctic asteroid. Antarct Res Ser 5:39-85

Pearse JS (1970) Reproductive periodicities of indo-pacific invertebrates in Gulf of Suez. 3. Echinoid Diadema setosum (leske). Bull Mar Sci 20:697-720

Pearse JS, Cameron RA (1991) Chapter 7: Echinodermata: Echinoidea In: Giese AC, Pearse JS, Pearse VB (eds) Reproduction of marine invertebrates, Vol VI. Echinoderms and lophophorates. The Boxwood Press, Pacific Grove, CA, p 513-662

Pearse JS, Giese AC (1966) Food, reproduction and organic constitution of the common Antarctic echinoid Sterechinus neumayeri (Meissner). Biol Bull (Woods Hole) 130: $387-401$

Peck LS (2005) Prospects for survival in the Southern Ocean: extreme temperature sensitivity of benthic species. Antarct Sci 17:497-507

Peck LS, Brockington S, Brey T (1997) Growth and metabolism in the Antarctic brachiopod Liothyrella uva. Phil Trans R Soc Lond B 352:851-858

Peck LS, Colman JG, Murray AWA (2000) Growth and tissue mass cycles in the infaunal bivalve Yoldia eightsi at Signy Island, Antarctica. Polar Biol 23:420428

Peck LS, Convey P, Barnes DKA (2006) Environmental constraints on life histories in Antarctic ecosystems: tempos, timings and predictability. Biol Rev 80:1-35 
Thompson RJ (1984) Partitioning of energy between growth and reproduction in three populations of the sea urchin Strongylocentrotus droebachiensis. In Engels W (ed) Advances in invertebrate reproduction 3. Elsevier Science, Amsterdam, p 425-431

Tyler PA, Reeves S, Peck LS, Clarke A, Powell D (2003)

Editorial responsibility: John Lawrence (Contributing Editor), Tampa, Florida, USA
Seasonal variation in the gametogenic ecology of the Antarctic scallop Adamussium colbecki. Polar Biol 26: 727-733

Yakovlev SN (1983) Reproductive cycle of the Antarctic sea urchin Sterechinus neumayeri in Davis Sea. Sov J Mar Biol 9:265-270

Submitted: March 7, 2006; Accepted: May 15, 2006 Proofs received from author(s): January 10, 2007 